\title{
Detection of Toxoplasma gondii oocysts in fresh vegetables and berry fruits
}

\author{
Cláudia S. Marques ${ }^{1,2}$, Susana Sousa ${ }^{1,2}$, António Castro ${ }^{1,2}$ and José Manuel Correia da Costa ${ }^{1,2^{*}}$
}

\begin{abstract}
Background: Toxoplasma gondii is the third most important contributor to health burden caused by food-borne illness. Ingestion of tissue cysts from undercooked meat is an important source of horizontal transmission to humans. However, there is an increasing awareness of the consumption of fresh fruit and vegetables, as a possible source for oocyst transmission, since this stage of the parasite can persist and remain infective in soil and water for long time. Herein, we outline findings related with detection of T. gondii oocysts in vegetables and berry fruits, which are usually raw consumed. The procedure includes the estimation of the number of oocysts.

Methods: Food samples were collected from local producers and supermarket suppliers. Toxoplasma gondii oocysts were concentrated after washing the samples by applying high resolution water filtration and immunomagnetic separation (method 1623.1: EPA 816-R-12-001-Jan 2012), in order to (i) remove potential Cryptosporidium spp. oocysts and Giardia spp. cysts present in the samples; and (ii) select T. gondii oocysts. Toxoplasma gondii oocyst detection and an estimation of their numbers was performed by conventional PCR and real time GPCR, using specific primers for a 183-bp sequence of the T. gondii repetitive DNA region. All PCR-positive DNA samples were purified and sequenced. Restriction enzyme digestion with EcoRV endonuclease confirmed the presence of the T. gondii DNA fragment. In addition, the presence of the parasite was observed by fluorescent microscopy, taking advantage of the oocysts autofluorescence under UV light.

Results: Forty percent of the analysed samples ( $95 \% \mathrm{Cl}: 25.5-56.5 \%$ ) presented the expected PCR and digested DNA fragments. These fragments were confirmed by sequencing. Microscopic autofluorescence supported the presence of T. gondii-like oocysts. The estimated mean ( \pm SE) oocyst concentration was $23.5 \pm 12.1$ oocysts $/ \mathrm{g}$, with a range of $0.6-179.9$ oocysts/g.
\end{abstract}

Conclusions: Our findings provide relevant evidence of contamination of fresh vegetables and berry fruits with $T$. gondii oocysts.

Keywords: Toxoplasma gondii, Oocysts, Immunomagnetic separation, PCR, Vegetables, Berry fruits

\section{Background}

Toxoplasma gondii is an intracellular protozoan (Apicomplexa: Coccidia) causing human and animal toxoplasmosis [1]. Protozoan infectivity is due to three parasitic stages: an

\footnotetext{
*Correspondence: jose.costa@insa.min-saude.pt

${ }^{2}$ Centre for Parasite Biology and Immunology, Department of Infectious Diseases, National Health Institute Dr Ricardo Jorge (INSARJ), Rua de Alexandre Herculano, 321, 4000-055 Porto, Portugal

Full list of author information is available at the end of the article
}

invasive tachyzoite; a bradyzoite in tissue cysts; and an environmental stage, the sporozoite, protected inside mature oocysts $[1,2]$. The global prevalence of toxoplasmosis is estimated to be around $30 \%$ with 10 million clinical cases [1-4] and it is ranked as the third most important contributor to health burden caused by food-borne illness in Europe [4]. Most infections in humans are asymptomatic. However, severe complications may occur during (i) congenital Toxoplasma infection, such as abortion, stillbirth and hydrocephalus in new-borns [1, 4, 5]; (ii) ocular toxoplasmosis,

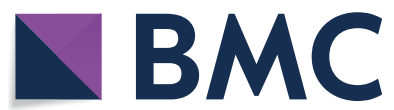

(c) The Author(s) 2020. This article is licensed under a Creative Commons Attribution 4.0 International License, which permits use, sharing, adaptation, distribution and reproduction in any medium or format, as long as you give appropriate credit to the original author(s) and the source, provide a link to the Creative Commons licence, and indicate if changes were made. The images or other third party material in this article are included in the article's Creative Commons licence, unless indicated otherwise in a credit line to the material. If material is not included in the article's Creative Commons licence and your intended use is not permitted by statutory regulation or exceeds the permitted use, you will need to obtain permission directly from the copyright holder. To view a copy of this licence, visit http://creativecommons.org/licenses/by/4.0/. The Creative Commons Public Domain Dedication waiver (http://creativecommons.org/publicdomain/zero/1.0/) applies to the data made available in this article, unless otherwise stated in a credit line to the data. 
with retinochoroidal lesions leading to chronic ocular disease [1, 2]; (iii) encephalitis in immunosuppressed patients $[1,4,5]$; and (iv) multivisceral toxoplasmosis due to atypical genotypes in South America [6-8]. A possible implication of T. gondii genetic diversity on the pathogenesis of toxoplasmosis has been postulated [9-11]. Consensually, current opinion is that the majority of horizontal transmissions to humans occurs after ingestion of tissue cysts in infected meat, or through water, raw fruit and vegetables contaminated with sporulated oocysts $[2,12,13]$. In vitro and in vivo experiments using mouse models have shown that infections due to oocysts are clinically more severe when compared to infections caused by tissue cysts (bradyzoites) [14]. However, the relative importance of transmission via tissue cysts versus oocysts is still unclear [2]. In addition, oocysts can remain viable for long periods in the environment and can resist chemical and physical treatment currently applied in water plants, including chlorination and ozone treatment [15-18]. This paved the way for an increasingly awareness related to drinking water and the consumption of raw fruit and vegetables as putative routes for oocyst transmission. So far, the detection of Toxoplasma oocysts in fruit and vegetables has been difficult, and no standardized methods are available. Moreover, findings outlined in the literature on this topic are scarce and/or controversial [19-26]. In this scenario, a laboratory approach was designed based on the experience gained with Method 1623.1/EPA for Cryptosporidium oocyst and Giardia cyst detection [27]. This approach involved: (i) the concentration of oocysts from large volumes of washing water (fruit and vegetables), according to Method 1623.1/EPA; and (ii) subsequent application of PCR for identification and quantification of T. gondii DNA [23, 26, 28-30]. Herein, we outline findings related with the detection of $T$. gondii oocysts in vegetables and berry fruits, as a contribution to a better comprehension of oocyst transmission to humans.

\section{Methods}

Food samples

A total of 35 bulk, packaged and ready-to-eat (RTE) vegetables and berry fruits were collected from local producers, provided by retail sellers, or bought in small and large-scale supermarkets between July 2018 and July 2019, in several locations in Portugal and Spain (Fig. 1). The choice of samples was based on expected market preferences of raw fruit and vegetables by Portuguese consumers, described by the Government agency "Instituto Nacional de Estatística" [31]. The food products included different varieties of lettuce (Lactuca sativa), watercress (Nasturtium officinale), coriander (Coriandrum sativum), parsley (Petroselinum crispum) carrots (Daucus carota sativus), arugula (Eruca vesicaria sativa), strawberries (Fragaria ananassa), raspberries (Rubus idaeus) and blueberries (Vaccinium myrtillus). Ready-to-eat mixed salads, with different varieties of lettuce (Lactuca sativa), arugula (Eruca vesicaria sativa), endive (Cichorium endivia), chicória-italiana (Cichorium intybus), carrots (Daucus carota sativus), red cabbage (Brassica oleracea var. capitata f. rubra) and lamb's lettuce (Valerianella locusta) were also included in this study. Laboratory sample treatment was performed immediately or in less than $24 \mathrm{~h}$ after refrigeration.

\section{Toxoplasma gondii oocyst recovery}

The concentration and recovery of $T$. gondii oocysts, as well as Cryptosporidium spp. oocysts and Giardia spp. cysts from fruit and vegetable samples were performed by Filtration/Immunomagnetic Separation (IMS)/Fluorescence Assay (FA) (Method 1623.1: Cryptosporidium and Giardia in water; US EPA 816-R-12-001-Jan 2012) [27]. Briefly, the fruit and vegetables were vigorously washed by manual swirling, for at least $10 \mathrm{~min}$ in large volumes of distilled water (between 10 and $80 \mathrm{l}$ ) in 20,50 or $100 \mathrm{l}$ tanks, accordingly to the size of each sample. Ten litres of distilled water were used to wash an average of $440 \mathrm{~g}$ of sample. The weight of each sample varied between 64-3600 g (Table 1); for washing water filtration, a $1 \mu \mathrm{m}$ Filta-Max ${ }^{\circledR}$ filter (IDEXX, Westbrook, ME, USA) applied to a peristaltic pump at three bar was used. Elution was performed in a Filta-Max ${ }^{\circledR}$ manual wash station, and concentrated into $3 \mathrm{ml}$ of phosphate-buffered solution (PBS) with $0.01 \%$ of Tween 20 (Merck KGaA, Darmstadt, Germany), after centrifugation at $1000 \times g$ for $10 \mathrm{~min}$ at room temperature. Magnetic beads conjugated with specific antibodies (Dynabeads ${ }^{\mathrm{TM}}$ GC-Combo; Thermo Fisher Scientific, Waltham, MA, USA) were added to the concentrate, and magnetized Cryptosporidium oocysts and Giardia cysts were removed from the extraneous material using a magnet (data not presented). The remaining suspension, containing putative T. gondii (PTG) oocysts were centrifuged $(1000 \times \mathrm{g}$ for $10 \mathrm{~min}$ at room temperature) and resuspended in $2-5 \mathrm{ml}$ of PBS.

\section{Toxoplasma gondii DNA detection and oocysts number estimation DNA extraction}

Two-hundred microliters of PTG suspension was centrifuged at $1000 \times g$ for $10 \mathrm{~min}$ at room temperature and the pellet resuspended in $200 \mathrm{ml}$ lysis buffer (QIAamp ${ }^{\circledR}$ DNA Mini Kit; Qiagen, Hilden, Germany). The disruption of the oocyst cell wall was performed with 4 freeze $\left(-20{ }^{\circ} \mathrm{C}\right) /$ thaw $\left(95^{\circ} \mathrm{C}\right)$ cycles. Prior to overnight incubation at $56{ }^{\circ} \mathrm{C}$ with $20 \mu$ l proteinase $\mathrm{K}$ (Qiagen), samples were treated with $1 \mathrm{ml}$ of InhibitEX buffer (Qiagen) that efficiently removes PCR inhibitors commonly present in environmental samples. The commercial kit, QIAamp ${ }^{\circledR}$ 


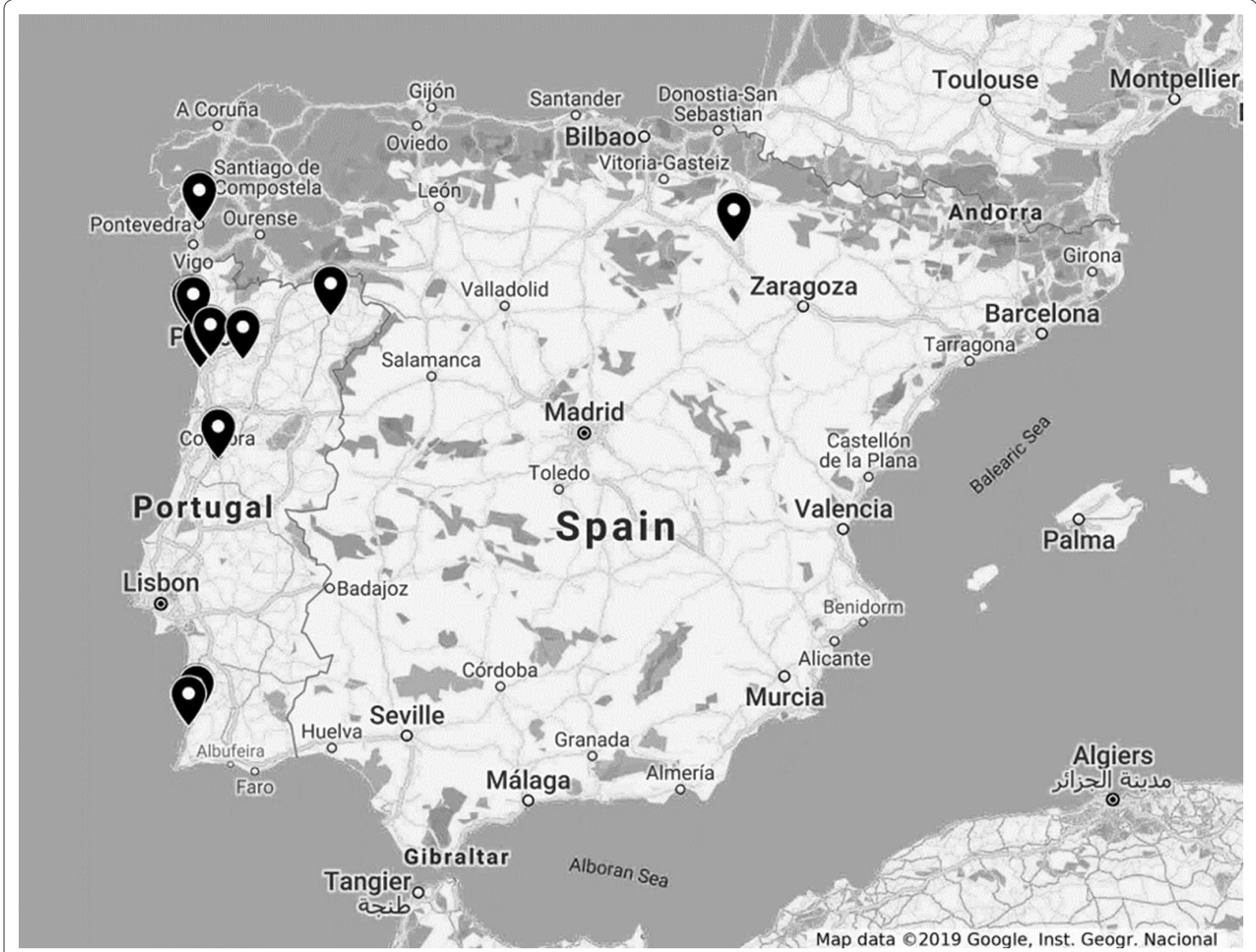

Fig. 1 Geographical origin of the collected samples. Fruit and vegetables were collected from local producers, provided by retail sellers, or bought in small- and large-scale supermarkets in several locations of Portugal and Spain

DNA Mini Kit (Qiagen), was used for DNA isolation according to the manufacturer's instructions.

\section{Conventional $P C R$ and sequencing}

Specific primers (FW: 5'-AGC CAC AGA AGG GAC AGA AG-3' and REV: 5'-TCC AGG AAA AGC AGC CAA G-3') targeting a 183-bp sequence of the 529-bp repetitive sequence of T. gondii [23, 26, 28-30] were designed (Primer3Plus and BLAST $^{\circledR}$ ) for DNA detection according to the MIQE (minimum information for publication of quantitative real-time PCR experiments) guidelines [32, 33]. These primers do not bind to any site of the H. hammondi 529-bp repetitive sequence (GenBank: EU493285.1), and no significant similarity was found between the primers' nucleotides and $H$. hammondi repetitive sequence. PCR amplification was performed with an initial polymerase activation step $\left(3 \mathrm{~min}\right.$ at $95{ }^{\circ} \mathrm{C}$ ), followed by 35 cycles of denaturation $\left(30 \mathrm{~s}\right.$ at $\left.95{ }^{\circ} \mathrm{C}\right)$, annealing $\left(30 \mathrm{~s}\right.$ at $\left.62{ }^{\circ} \mathrm{C}\right)$ and extension $\left(30 \mathrm{~s}\right.$ at $72{ }^{\circ} \mathrm{C}$ ), followed by a final extension step of $10 \mathrm{~min}$ at $72{ }^{\circ} \mathrm{C}$. The amplification reaction mixture consisted of $12.5 \mu$ l DreamTaq ${ }^{\text {TM }}$ Hot Start Green PCR Master Mix $2 \times$ (Thermo Fisher Scientific), $600 \mathrm{nM}$ of each primer (Eurofins Genomics, Ebersberg, Germany) and $5 \mu$ of template DNA in a $25 \mu \mathrm{l}$ reaction volume. Amplifications were performed in a C1000 Touch $^{\mathrm{TM}}$ thermal cycler (Bio-Rad, Hercules, CA, USA). PCR products (183 bp) were observed in a Gel DocTM XR+ (Bio-Rad) and analysed using Image LabTM Software (Bio-Rad). In all PCR experiments, a positive control (genomic DNA isolated from $10^{5}$ T. gondii ME49 oocysts) and a negative control (water template) were used. Additionally, all of the negative samples were retested for the presence of PCR inhibitors by adding $1 \mu \mathrm{l}$ of $T$. gondiipositive control to the $5 \mu \mathrm{l}$ of DNA template. Positive PCR fragments were purified (IllustraTM GFXTM PCR DNA and Gel Band Purification kit; GE HealthCare, IL, Chicago, USA) from a low melting 2\% agarose gel (Lonza, Basel, Switzerland) and sequenced using Sanger sequencing services from GATC Biotech (Eurofins Genomics, Ebersberg, 


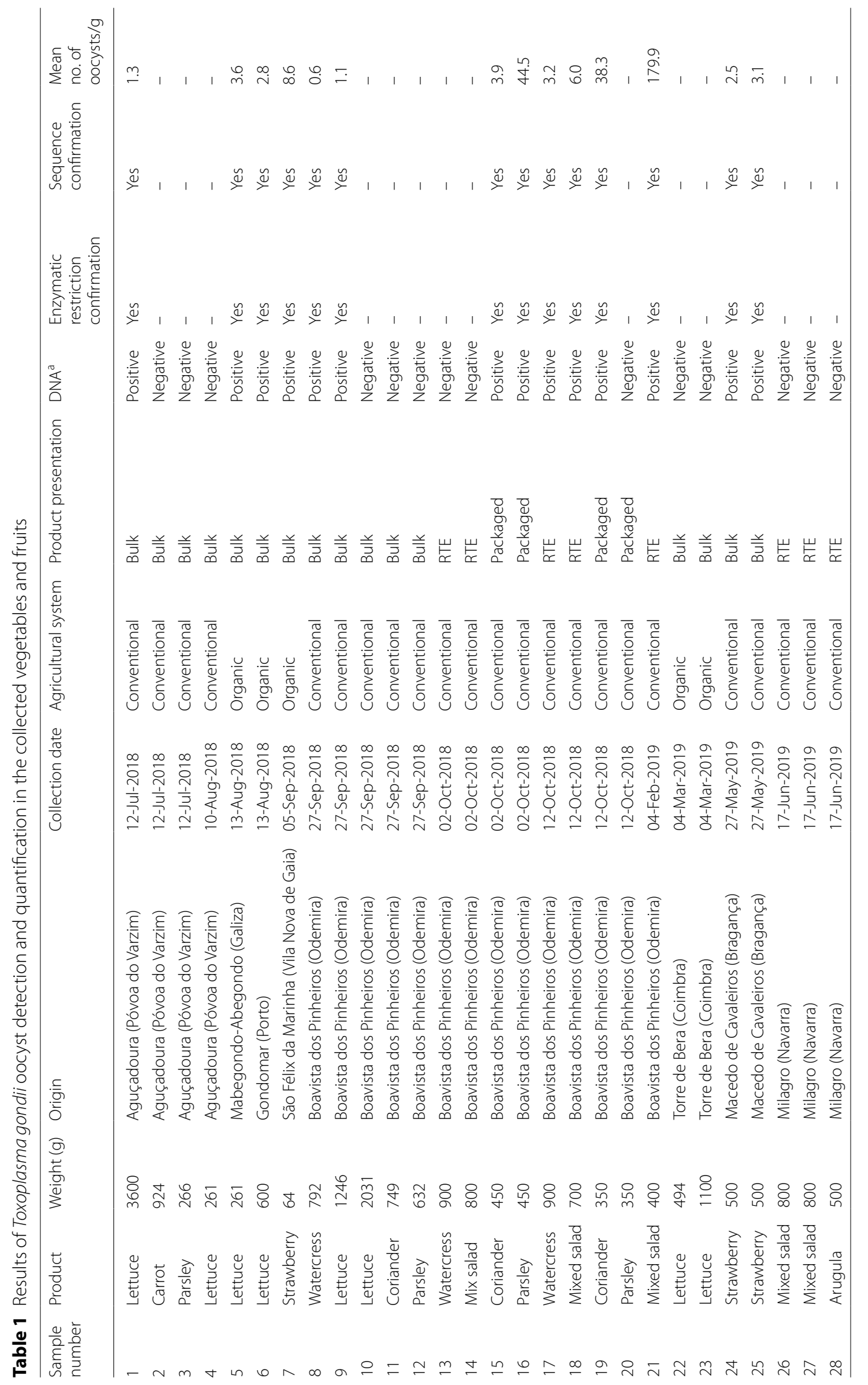




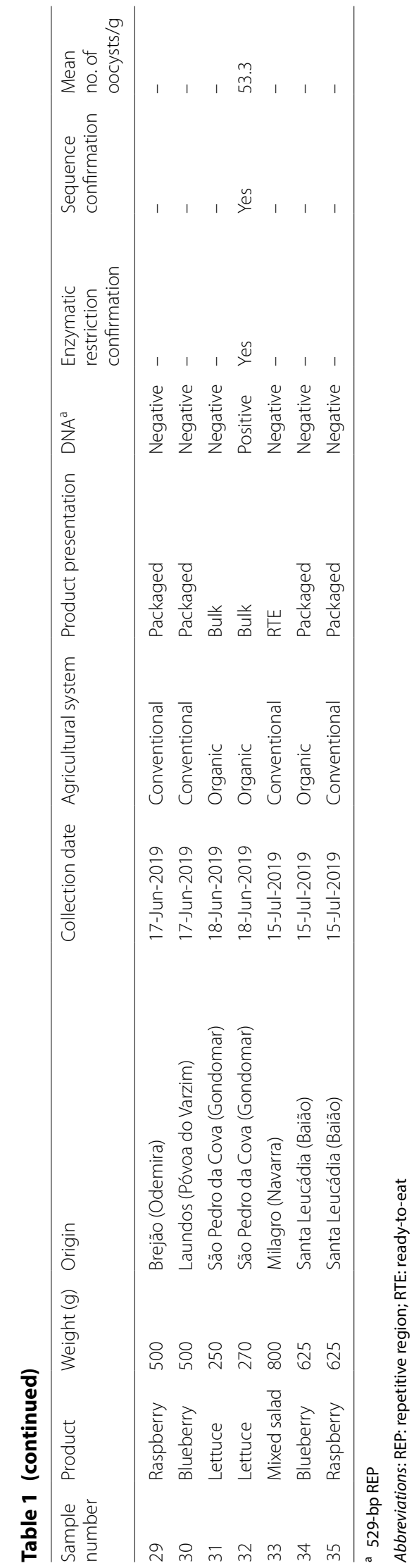


Germany). Sequence comparison was made with already published sequences (GenBank: AF146527.1) using the NCBI Basic Local Alignment Search Tool (BLAST).

\section{Quantitative real-time $P C R$}

A quantitative (qPCR) method based on a standard curve was used to estimate the initial number of oocysts per gram of vegetable or fruit. Briefly, a standard template was obtained after purification of the positive control $(T$. gondii ME49 oocysts) PCR product and DNA concentration was measured with a NanoDrop 1000 spectrophotometer (ThermoFisher Scientific, Waltham, MA, USA). The DNA copy number/ $\mu$ l was calculated and two series of a ten-fold serial dilution of the DNA (from $1 \times 10^{6}$ to $1 \mathrm{copy} / \mu \mathrm{l}$ ) were prepared. qPCR was carried out in a final volume of $20 \mu \mathrm{l}$, using $10 \mu \mathrm{l}$ of SsoAdvanced ${ }^{\mathrm{TM}}$ Universal SYBR ${ }^{\circledR}$ Green Supermix $(2 \times)$ (Bio-Rad) and $350 \mathrm{nM}$ of each specific primer (previously used for conventional PCR) and $2 \mu \mathrm{l}$ of the DNA sample or standard dilution. The plates were sealed and centrifuged at $1000 \times g$ for $1 \mathrm{~min}$, at room temperature. The cycling conditions for the qPCR CFX96 Touch real-time instrument (Bio-Rad) were as follows: initial denaturation at $98^{\circ} \mathrm{C}$ for $3 \mathrm{~min}$; followed by 35 cycles at $98{ }^{\circ} \mathrm{C}$ for $15 \mathrm{~s}$; then $62{ }^{\circ} \mathrm{C}$ for $30 \mathrm{~s}$. Melting curve analysis was also performed at the end of each PCR run $\left(65-95^{\circ} \mathrm{C}\right.$ at $\left.0.5^{\circ} \mathrm{C} / 5 \mathrm{~s}\right)$. qPCR of the standard dilution gradient and the DNA isolated from fruit and vegetable samples were run in duplicate and in the same plate. The absolute quantification of the initial DNA copy number/ $\mu \mathrm{l}$ and estimation of the number of oocysts per gram of each environmental sample was calculated by comparing the quantification cycle threshold $(\mathrm{Cq})$ values of the environmental samples with the standard curve taking into account the variation of the 529-bp repetitive sequence and the ploidy of the T. gondii oocysts.

\section{Restriction enzyme digestion}

Purified positive PCR fragments were subject to restriction enzyme digestion with the endonuclease EcoRV (New England Biolabs, Ipswich, MA, USA). The reaction was performed in a volume of $10 \mu \mathrm{l}$ with $5 \mu \mathrm{l}$ of DNA, $1 \mu \mathrm{l}$ of the enzyme and $1 \mu \mathrm{l}$ of $10 \times$ NEBuffer 3.1, according to the manufacturer's instructions. Each sample was incubated at $37^{\circ} \mathrm{C}$ for $1 \mathrm{~h}$. Additionally, purified T. gondii PCR fragments and uncut experimental DNA were used as controls. The digested fragments (74 bp and $109 \mathrm{bp}$ ) were electrophoresed on a $2 \%$ high-resolution agarose gel (Sigma-Aldrich) and analysed using a Gel DocTM XR+ (Bio-Rad).

\section{Epifluorescence microscopy}

Twenty-five microliters of the PTG suspension was diluted (1:2) and air-dried onto a 2-well SuperStick ${ }^{\text {TM }}$ Slide (Waterborne $^{\mathrm{TM}}$, Inc., New Orleans, LA, USA) chemically treated to increase adhesion of the oocysts. Fixation was performed for 2 min with absolute methanol (Panreac Química SLU, Castellar del Vallès, Spain) and the slides were allowed to dry completely. As a positive control, a slide was prepared with $10^{5}$ T. gondii ME49 oocysts (kindly provided by J. T. Dubey). The background fluorescence was reduced by adding Evans Blue dye solution (BlockOut Counterstain; Waterborne $^{\mathrm{TM}}$, Inc.), slides were rinsed with PBS and completely air-dried before being mounted with DPX mounting media (Merck KGaA, Darmstadt, Germany). Oocysts were visualized using a Nikon fluorescence microscope (Nikon Optiphot 2; Melville, NY, USA), under bright field and ultraviolet (UV) filter block (excitation $335 \mathrm{~nm}$; emission $450 \mathrm{~nm}$ ), based on the autofluorescent nature of the oocyst wall due to Tyrrich proteins $[18,34]$. Images were captured at $400 \times$ magnification using a PowerShot A630 digital camera (Canon, Amstelveen, Holland).

\section{Statistical analysis}

Graphpad Prism version 7.02 (San Diego, CA, USA) was used for statistical analysis. The $95 \%$ confidence intervals ( $95 \% \mathrm{CI}$ ) for the population proportions were calculated using the modified Wald method [35]. Fisher's exact test was used to find out differences for the different categorical variables. The non-parametric Mann-Whitney U-test was used to compare the number of oocysts per gram in each food group. A two-tailed $P$-value of less than 0.05 was considered significant.

\section{Results}

\section{Sampling}

A total of $25 \mathrm{~kg}$ of fresh products distributed in $35 \mathrm{sam}$ ples were analysed and results are shown in Table 1 . These comprised 18 bulk samples, corresponding to $14.5 \mathrm{~kg}$ and 17 samples of packaged and RTE corresponding to $10.5 \mathrm{~kg}$; 28 samples $(21.7 \mathrm{~kg})$ of fresh vegetables (lettuce, watercress, parsley, coriander, arugula, carrots and mixed salads) and $7(3.3 \mathrm{~kg})$ of berry fruits (strawberry, raspberry and blueberry); 27 samples ( $21.3 \mathrm{~kg}$ ) were provided from conventional agriculture systems and 8 samples $(3.7 \mathrm{~kg})$ from organic agriculture.

\section{Toxoplama gondii DNA detection}

Toxoplasma gondii detection was performed by conventional PCR and a 183-bp gel band corresponding to the specific DNA fragment of the T. gondii repetitive region (GenBank: AF146527.1) was observed in 14 out of the 35 
Table 2 Prevalence rate of Toxoplasma gondii in different groups of fruit and vegetables

\begin{tabular}{llll}
\hline Samples & \multicolumn{2}{l}{ Toxoplasma gondii DNA detection } & P-value \\
\cline { 2 - 3 } & Negative $(n, \%)$ & Positive $(n, \%)$ & \\
\hline Total & $21(60.0)$ & $14(40.0)$ & \\
Product presentation & & & \\
Bulk & $9(50.0)$ & $9(50.0)$ & $P=0.499$ \\
RTE/packaged & $11(64.7)$ & $6(35.3)$ & \\
Type of product & & & \\
Vegetables & $16(57.1)$ & $12(42.9)$ & $P=1.000$ \\
Berry fruits & $4(57.1)$ & $3(42.9)$ & \\
Agricultural system & & & \\
Conventional & $16(59.3)$ & $11(40.7)$ & $P=0.700$ \\
Organic & $4(50.0)$ & $4(50.0)$ & \\
Season & & & \\
Spring/summer & $12(63.2)$ & $7(36.8)$ & $P=0.506$ \\
Autumn/winter & $8(50.0)$ & $8(50.0)$ & \\
\hline
\end{tabular}

Notes: Contingency tables were constructed in order to compare categorical variables. The Fisher's exact test was used and $P>0.05$ indicates non-significant associations

Abbreviations: $n$, number of samples; $\%$, percentage

(40.0\%) analysed samples (95\% CI: 6.5-25.5\%). Statistical analysis of contingency tables showed no significant differences $(P>0.05)$ for the different categorical variables, such us the type of products, the season when they were collected, the type of agriculture system applied and Bulk or RTE products (Table 2). Sequence analysis confirmed

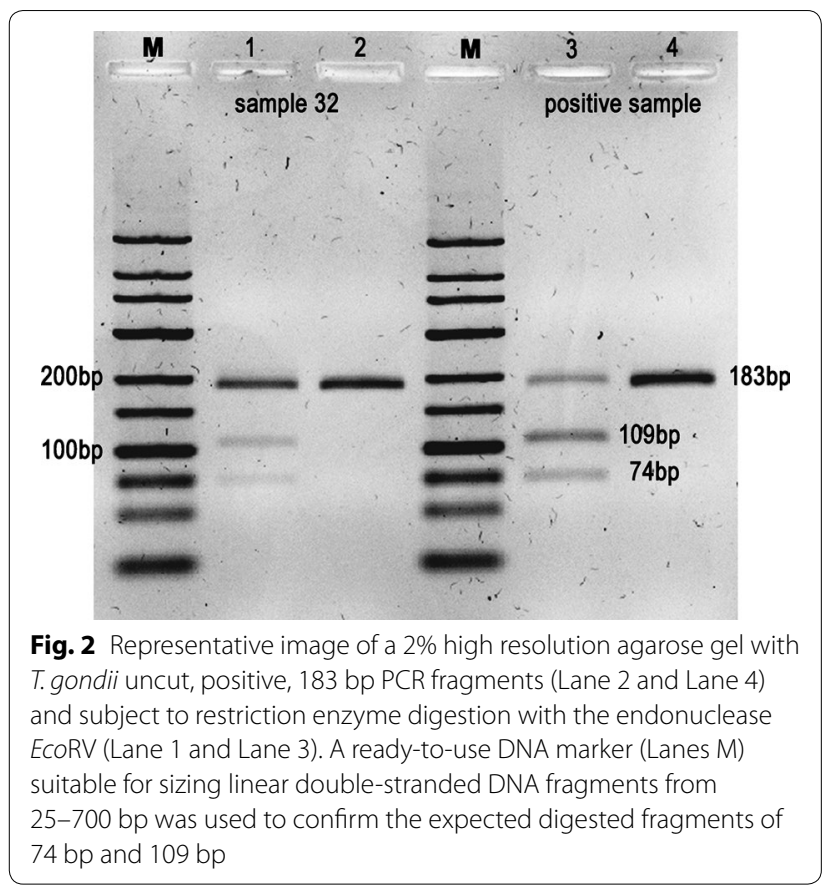

that the obtained amplicon of all positive samples had more than $95 \%$ nucleotide similarity with the 529-bp $T$. gondii repetitive region (GenBank: AF146527.1) (Table 1). Moreover, two bands of expected sizes (109 bp and 74 bp) were observed after EcoRV DNA enzymatic digestion (Fig. 2), confirming T. gondii DNA sequence.

\section{Estimation of the number of $T$. gondii oocysts}

Real-time qPCR was used to estimate the initial number of oocysts present in each gram of vegetable or fruit. Quantification was performed by using as a standard, a $T$. gondii DNA gradient of a known initial number of DNA copies/ $\mu$ l. Amplification efficiencies were calculated and were always between $90-110 \%$. In addition, melt curve analysis allowed confirmation of the specific T. gondii amplified sequence. The diagnostic melting temperature $(\mathrm{Tm})$ peak was $86.5 \pm 1{ }^{\circ} \mathrm{C}$. The concentration of Toxoplasma from the fruit and vegetables varied between $0.6-179.9$ oocysts/g (Table 1 ), with a mean number $( \pm \mathrm{SE})$ of $23.5 \pm 12.1$ oocysts/g. A significantly higher number of oocysts/g was found from RTE/packaged samples $(45.9 \pm 27.8$ oocysts/g) when compared with the mean number of oocysts/g present in bulk products $(8.5 \pm 5.6$ oocyst/g) (Mann-Whitney U-test: $P=0.036$ ) (Fig. 3a). No statistically significant differences $(P>0.05)$ were found when comparing the number of oocysts/g in products originally from conventional or organic agriculture, between fruit and vegetables or the season when the products were collected (Fig. 3b-d).

\section{Toxoplasma gondii oocysts autofluorescence}

Direct visualization of $T$. gondii oocyst autofluorescence was performed using an epifluorescent microscope. In slides from all PCR-positive samples we observed T. gondii-like oocysts, based on morphology and size (between $10-15 \mu \mathrm{m}$ in diameter), and the pale blue glow when illuminated with a UV light source. The majority of the samples presented unsporulated oocysts. However, sporulated oocysts were observed in one of the strawberry samples.

\section{Discussion}

Water and food matrices may be accidentally contaminated by environmental oocysts $[12,13]$. Thus far, there are no standard methods or consensual tools described for oocyst identification and quantification from these matrices. The lack of standardised methods probably sustains the exclusion of $T$. gondii from regular surveillance systems $[12,13,26]$. In order to estimate the prevalence of T. gondii oocysts in fresh fruit and vegetables, we have designed an approach described herein. For molecular detection of the parasite, we have selected a consensual 

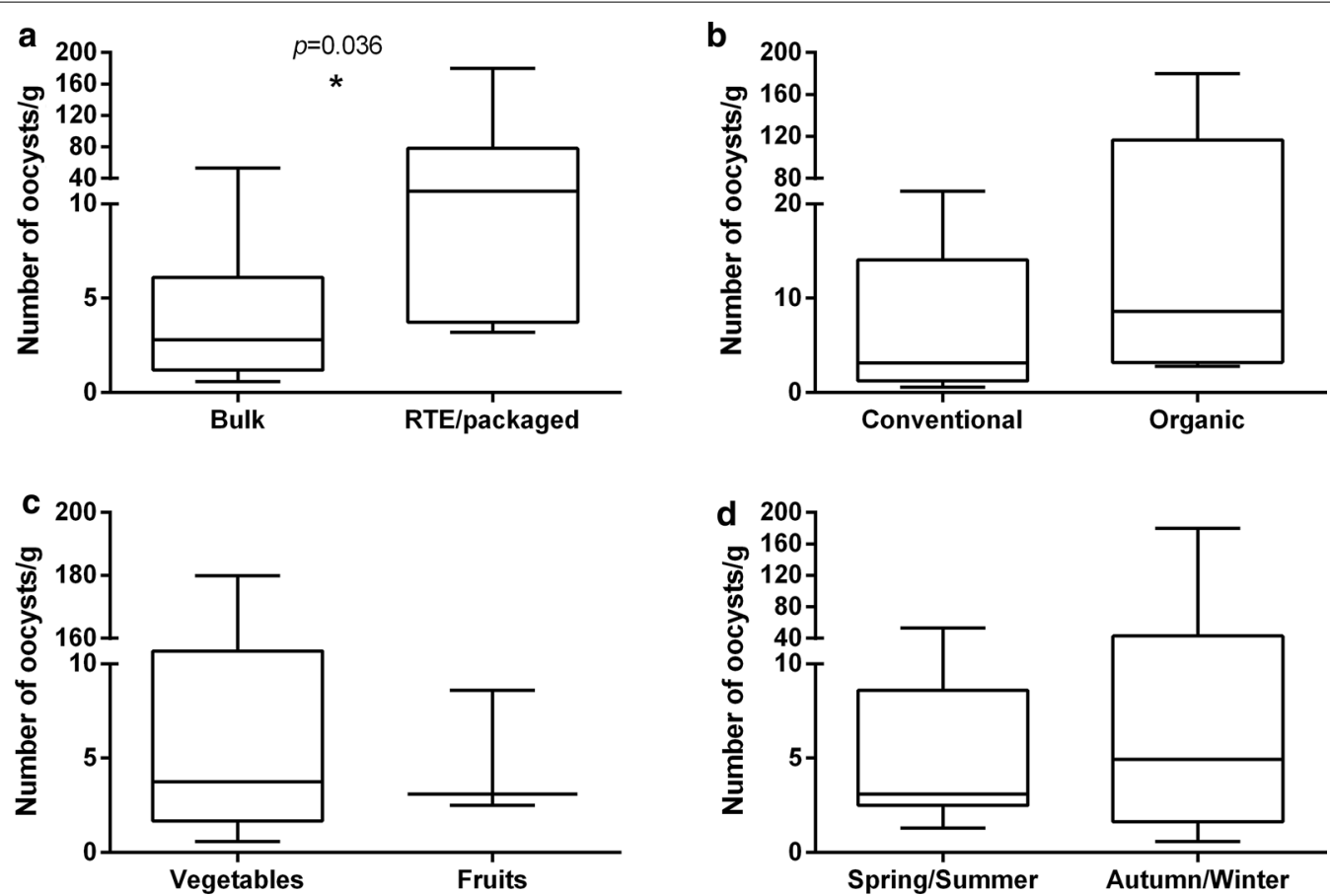

Fig. 3 Box and whiskers diagrams comparing the estimated number of oocysts per gram, between bulk and RTE/packaged products (a), conventional and organic agriculture system (b), fruit and vegetables (c) and food items collected in spring/summer and autumn/winter (d), quantified by qPCR. The non-parametric Mann-Whitney U-test was used to compare the estimated number of oocysts per gram between the groups. ${ }^{*} P=0.036$

specific DNA fragment of the T. gondii repetitive region [28]. The 529-bp DNA fragment was amplified in $40 \%$ of all samples, with an estimated mean of 23.5 oocysts per gram of product. Our findings indicate a higher prevalence compared to other studies [19-26]. However, critical analysis of the data in Table 3, evidences major differences related to: (i) sampling design; (ii) DNA target strategy; and of relevance to this particular study (iii) the choice of oocyst recovery method. In our opinion, the choice of the Filta-Max ${ }^{\circledR}$ System (IDEXX), for highresolution filtration of large volumes of washing water, increases oocyst recovery. Consequently, it increases the sensitivity of the detection method. Complementary to this, the execution of Method 1623.1 [27] seems to be an advisable strategy for removing Cryptosporidium spp. oocysts and Giardia spp. cysts and separating them from potential T. gondii oocysts present in the sample washing water. Indeed, high-grade filtration followed by immunomagnetic separation of water samples has been described as a more accurate method for parasite concentration when compared with membrane filtration and centrifugation [36] or sucrose gradient separation [37].

In our study, $T$. gondii DNA fragments were confirmed by sequencing and by DNA digestion with a restriction enzyme. Enzymatic digestion with EcoRV endonuclease suggests specificity and excludes cross-amplification of non-target organisms, such as Hammondia hammondi; this closely related apicomplexan presents a homologous region with around $84 \%$ sequence identity with the 529 bp repeat region of $T$. gondii [38]. The selected endonuclease $E c o$ RV does not bind to any recognition site of the $H$. hammondi repetitive sequence, consequently, DNA cleavage does not occur.

Slides from PCR-positive samples were examined under epifluorescent microscopy and autofluorescent structures, compatible with T. gondii unsporulated oocysts in morphology and size (between 10-15 $\mu \mathrm{m}$ in diameter) were observed. A sporulated oocyst was observed in one sample. Data concerning the direct microscopic examination of oocysts in fresh vegetables are scarce $[19,21]$. Indeed, no clear references to the observation of $T$. gondii sporulated oocysts has yet been described in fruit or vegetables. On the other hand, T. gondii oocysts are morphologically indistinguishable from the oocysts of related coccidian parasites, not infectious to humans, such as Hammondia spp. and Neospora caninum [13]; debris present in the samples may affect the ability to visualize small 


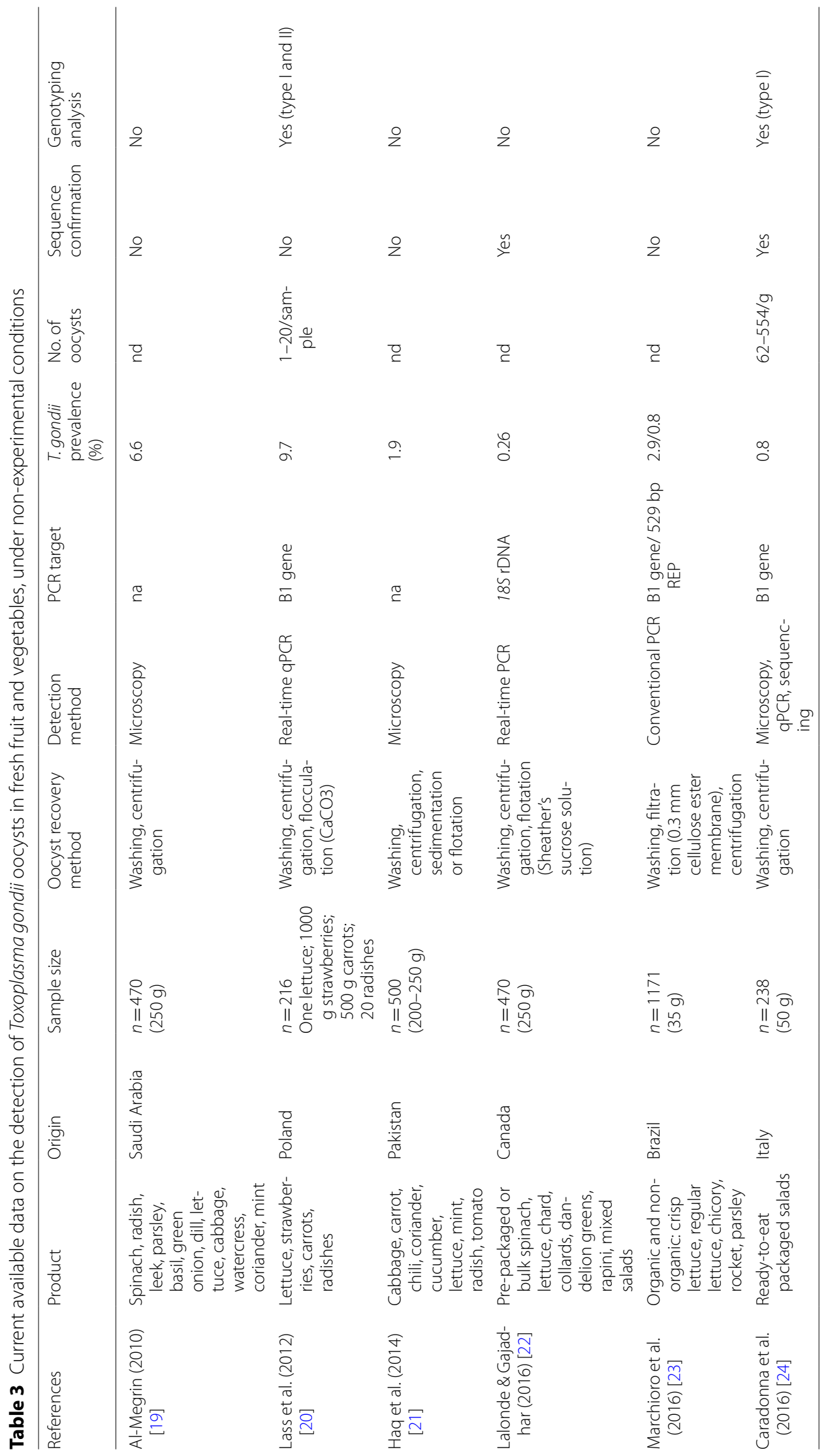




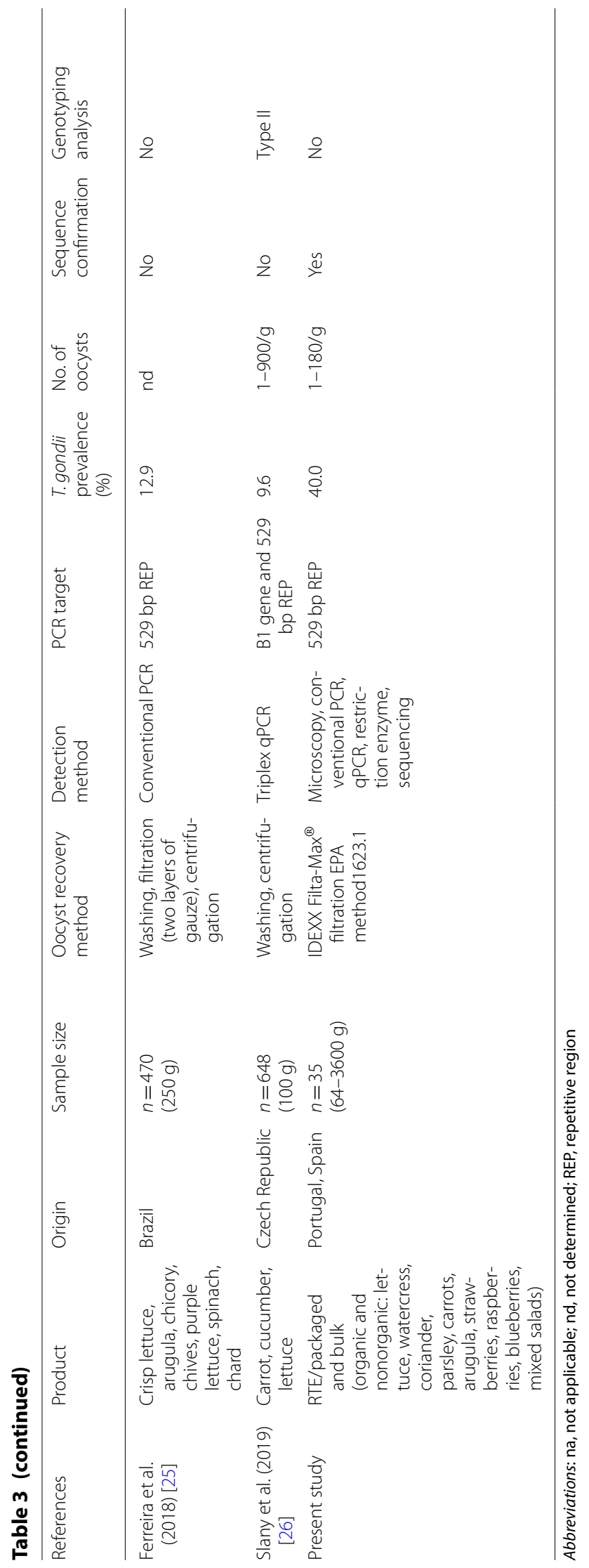


fluorescent structures such as autofluorescent oocysts, and so far there are no commercial antibodies to implement a specific immunomagnetic separation protocol. Therefore, and in the absence of standard methods for oocysts observation, T. gondii confirmation always requires molecular identification. Our findings suggest no significant seasonal variation or differences between the type of agriculture system applied. Additionally, no significant differences between the prevalence of $T$. gondii in the leafy vegetables or fruits were observed. Although a statistically significant difference in the proportion, has not been observed between bulk/ RTE and positive $T$. gondii DNA amplification, curiously, a remarkably higher concentration of Toxoplasma oocysts was found in RTE and packaged fruit and vegetables, when compared to bulk products. So far, we have no clear explanation for this result. However, it is reasonable to speculate about the management of the washing systems used in food industry. Trevisan et al. [39] referred that managing water sustainably in agriculture means increased utilization of wastewater for irrigation, reusing freshwater to wash the products and therefore increasing the chances for RTE/packaged fruit and vegetables to become contaminated [39]. Nevertheless, testing water samples from washing/packing facilities and the water used for irrigation of bulk products are warranted in order to decipher the degree of Toxoplasma oocyst contamination on fruit and vegetables. In addition, genotyping should be carried out in all positive-PCR samples, for risk assessment evaluation.

\section{Conclusions}

Our findings sustain that consumption of raw fruit and vegetables may be a source of T. gondii infection in humans. They also emphasise the need of a procedure accepted with a consensus as the "gold standard" method for the recovery, detection and quantification of $T$. gondii oocysts and validated for use with fresh fruit and vegetables. Major improvements are still required for routine application at the industrial level or for food testing in laboratories for detection of $T$. gondii oocysts.

\begin{abstract}
Abbreviations
BLAST: basic local alignment search tool; Cl: confidence interval; FA: fluorescence assay; IMS: immunomagnetic separation; MIQE: minimum information for publication of quantitative real-time PCR experiments; PBS: phosphatebuffered solution; PTG: putative T. gondii;; qPCR: quantitative PCR; RE: restriction enzyme; RTE: ready-to-eat; SE: standard error; Tm: melting temperature.
\end{abstract}

\section{Acknowledgements}

The authors would like to thank J. P. Dubey for kindly providing the T. gondii ME49 oocysts used in this work and Dr Margarida Saraiva for her critical advice regarding the conception and design of the experimental procedure and discussion of the results. The authors would also like to acknowledge SONAE MC SGPS, S.A., Vitacress Portugal S.A., and HORPOZIM association for providing some of the fruit and vegetables used in this study.

\section{Authors' contributions}

CSM, SS, AC and JMC participated in the design the experiments, the conception of the study, drafted and review the manuscript. CSM carried out the experiments and CSM and JMC analysed the data. All authors read and approved the final manuscript.

\section{Funding}

This study was supported by the Horizon 2020 project SafeConsume (Grant Agreement No. 727580).

\section{Availability of data and materials}

Data supporting the conclusions of this article are included within the article. The datasets used and analysed in the present study are available from the corresponding author upon reasonable request.

\section{Ethics approval and consent to participate}

Not applicable.

\section{Consent for publication}

Not applicable.

\section{Competing interests}

The authors declare that they have no competing interests.

\section{Author details}

${ }^{1}$ Centre for the Study in Animal Science (ICETA), University of Porto, Porto, Portugal. ${ }^{2}$ Centre for Parasite Biology and Immunology, Department of Infectious Diseases, National Health Institute Dr Ricardo Jorge (INSARJ), Rua de Alexandre Herculano, 321, 4000-055 Porto, Portugal.

Received: 11 November 2019 Accepted: 26 March 2020

Published online: 08 April 2020

\section{References}

1. Dubey JP. Toxoplasmosis of animals and humans. 2nd ed. Boca Raton: CRC Press, Taylor \& Francis Group; 2010.

2. Robert-Gangneux F, Dardé ML. Epidemiology of and diagnostic strategies for toxoplasmosis. Clin Microbiol Rev. 2012;25:264-96.

3. Montoya JG, Liesenfeld O. Toxoplasmosis. Lancet. 2004;363:1965-76.

4. WHO. The burden of foodborne diseases in the WHO European Region. Copenhagen:WHO; 2017. http://www.euro.who.int/_data/assets/pdf_ file/0005/402989/50607-WHO-Food-Safety-publicationV4_Web.pdf?ua=1 Accessed 17 Feb 2020.

5. Koutsoumanis $K$, Allende A, Alvarez-Ordóñez A, Bolton D, Bover-Cid S, Chemaly $\mathrm{M}$, et al. Public health risks associated with food-borne parasites. EFSA J. 2018;16:e05495.

6. Demar M, Ajzenberg D, Maubon D, Djossou F, Panchoe D, Punwasi W, et al. Fatal outbreak of human toxoplasmosis along the Maroni river: epidemiological, clinical, and parasitological aspects. Clin Infect Dis. 2007;45:88-95.

7. Demar M, Hommel D, Djossou F, Peneau C, Boukhari R, Louvel D, et al. Acute toxoplasmoses in immunocompetent patients hospitalized in an intensive care unit in French Guiana. Clin Microbiol Infect. 2012;18:221-31.

8. Pomares C, Devillard S, Holmes TH, Olariu TR, Press CJ, Ramirez R, et al. Genetic characterization of Toxoplasma gondii DNA samples isolated from humans living in north America: an unexpected high prevalence of atypical genotypes. J Infect Dis. 2018;218:1783-91.

9. Boothroyd JC, Grigg ME. Population biology of Toxoplasma gondii and its relevance to human infection: do different strains cause different disease? Curr Opin Microbiol. 2002;5:438-42.

10. Xiao J, Yolken RH. Strain hypothesis of Toxoplasma gondii infection on the outcome of human diseases. Acta Physiol. 2015;213:828-45.

11. Galal L, Hamidović A, Dardé ML, Mercier M. Diversity of Toxoplasma gondii strains at the global level and its determinants. Food Waterborne Parasitol. 2019;15:e00052. 
12. Dumètre A, Dardé ML. How to detect Toxoplasma gondii oocysts in environmental samples? FEMS Immunol Med Microbiol. 2003;27:651-61.

13. Shapiro K, Bahia-Oliveira L, Dixon B, Dumètre A, de Wit LA, VanWormer E, et al. Environmental transmission of Toxoplasma gondii: oocysts in water, soil and food. Food Waterborne Parasitol. 2019;15:e00049.

14. Dubey JP. Comparative infectivity of oocysts and bradyzoites of Toxoplasma gondii for intermediate (mice) and definitive (cats) hosts. Vet Parasitol. 2006;140:69-75.

15. Dumètre $A$, Le Bras C, Baffet $M$, Meneceur $P$, Dubey JP, Derouin F, et al. Effects of ozone and ultraviolet radiation treatments on the infectivity of Toxoplasma gondii oocysts. Vet Parasitol. 2008;153:209-13.

16. Dumètre A, Dubey JP, Ferguson DJP, Bongrand P, Azas N, Puech PH Mechanics of the Toxoplasma gondii oocyst wall. Proc Natl Acad Sci USA. 2013;110:11535-40.

17. Mirza Alizadeh A, Jazaeri S, Shemshadi B, Hashempour-Baltork F, Sarlak Z, Pilevar Z, et al. A review on inactivation methods of Toxoplasma gondii in foods. Pathog Glob Health. 2018;112:306-19.

18. Freppel W, Ferguson DJP, Shapiro K, Dubey JP, Puech P-H, Dumètre A. Structure, composition, and roles of the Toxoplasma gondii oocyst and sporocyst walls. Cell Surf. 2019:5:e100016.

19. Al-Megrin WAI. Prevalence intestinal parasites in leafy vegetables in Riyadh, Saudi Arabia. Int J Trop Med. 2010;5:20-3.

20. Lass A, Pietkiewicz H, Szostakowska B, Myjak P. The first detection of Toxoplasma gondii DNA in environmental fruits and vegetables samples. Eur J Clin Microbiol Infect Dis. 2012;31:1101-8.

21. Haq SU, Maqbool A, Khan UJ, Yasmin G, Sultana R. Parasitic contamination of vegetables eaten raw in Lahore. Pak J Zool. 2014:46:1303-9.

22. Lalonde LF, Gajadhar AA. Detection of Cyclospora cayetanensis, Cryptosporidium spp., and Toxoplasma gondii on imported leafy green vegetables in Canadian survey. Food Waterborne Parasitol. 2016;2:8-14.

23. Marchioro AA, Tiyo BT, Colli CM, De Souza CZ, Garcia JL, Gomes ML, et al. First detection of Toxoplasma gondii DNA in the fresh leafs of vegetables in south America. Vector Borne Zoonotic Dis. 2016;16:624-6.

24. Caradonna T, Marangi M, Del Chierico F, Ferrari N, Reddel S, Bracaglia G, et al. Detection and prevalence of protozoan parasites in ready-to-eat packaged salads on sale in Italy. Food Microbiol. 2017;67:67-75.

25. Ferreira FP, Caldart ET, Freire RL, Mitsuka-Breganó R, de Freitas FM, Miura $A C$, et al. The effect of water source and soil supplementation on parasite contamination in organic vegetable gardens. Rev Bras Parasitol Vet. 2018;27:327-37.

26. Slany M, Dziedzinska R, Babak V, Kralik P, Moravkova M, Slana I. Toxoplasma gondii in vegetables from fields and farm storage facilities in the Czech Republic. FEMS Microbiol Lett. 2019;366:fnz170.

27. EPA. Method 1623.1: Cryptosporidium and Giardia in water by filtration/ IMS/FA. Washington: United States Environmental Protection Agency; 2012. https://nepis.epa.gov/Exe/ZyPDF.cgi/P100J7G4.PDF?Dockey=P100J 7G4.PDF. Accessed 17 Feb 2020.
28. Homan WL, Vercammen M, De Braekeleer J, Verschueren H. Identification of a 200- to 300-fold repetitive 529 bp DNA fragment in Toxoplasma gondii, and its use for diagnostic and quantitative. Int J Parasitol. 2000;30:69-75.

29. Wells B, Shaw H, Innocent G, Guido S, Hotchkiss E, Parigi M, et al. Molecular detection of Toxoplasma gondii in water samples from Scotland and a comparison between the $529 \mathrm{bp}$ real-time PCR and ITS1 nested PCR. Water Res. 2015;87:175-81.

30. Lalle M, Possenti A, Dubey JP, Pozio E. Loop-mediated isothermal amplification-lateral-flow dipstick (LAMP-LFD) to detect Toxoplasma gondii oocyst in ready-to-eat salad. Food Microbiol. 2018;70:137-42.

31. Instituto Nacional de Estatística. Balança alimentar portuguesa-2012-2016. Lisboa-Portugal; 2017. https://www.ine.pt/xport al/xmain?xpid=INE\&xpgid=ine_publicacoes\&PUBLICACOESpub boui $=289818234 \&$ PUBLICACOESmodo $=2 \&$ xlang $=$ pt. Accessed 17 Feb 2020.

32. Bustin S, Huggett J. qPCR primer design revisited. Biomol Detect Quantif. 2017;14:19-28.

33. Bustin SA, Benes V, Garson JA, Hellemans J, Huggett J, Kubista M, et al. The MIQE guidelines: minimum information for publication of quantitative real-time PCR experiments. Clin Chem. 2009;55:611.

34. Lindquist HDA, Bennett JW, Hester JD, Ware MW, Dubey JP, Everson WV. Autofluorescence of Toxoplasma gondii and related coccidian oocysts. J Parasitol. 2003:89:865-7.

35. Agresti A, Coull BA. Approximate is better than "exact" for interval estimation of binomial proportions. Am Stat. 1998;52:119-26.

36. Dumètre A, Dardé ML. Immunomagnetic separation of Toxoplasma gondi oocysts using a monoclonal antibody directed against the oocyst wall. J Microbiol Methods. 2005;61:209-17.

37. Moulin L, Richard F, Stefania S, Goulet M, Gosselin S, Gonçalves A, et al. Contribution of treated wastewater to the microbiological quality of Seine river in Paris. Water Res. 2010;44:5222-31.

38. Schares G, Herrmann DC, Beckert A, Schares S, Hosseininejad M, Pantchev $\mathrm{N}$, et al. Characterization of a repetitive DNA fragment in Hammondia hammondi and its utility for the specific differentiation of H. hammondi from Toxoplasma gondii by PCR. Mol Cell Probes. 2008;22:244-51.

39. Trevisan C, Torgerson PR, Robertson LJ. Foodborne parasites in Europe: present status and future Trends. Trends Parasitol. 2019:35:695-703.

\section{Publisher's Note}

Springer Nature remains neutral with regard to jurisdictional claims in published maps and institutional affiliations.
Ready to submit your research? Choose BMC and benefit from:

- fast, convenient online submission

- thorough peer review by experienced researchers in your field

- rapid publication on acceptance

- support for research data, including large and complex data types

- gold Open Access which fosters wider collaboration and increased citations

- maximum visibility for your research: over 100M website views per year

At BMC, research is always in progress.

Learn more biomedcentral.com/submissions 